\title{
Parent(s): The Biggest Influence in the Education of African- American Football Student-Athletes
}

Jamel K. Donnor

William \& Mary School of Education, jkdonnor@wm.edu

Follow this and additional works at: https://scholarworks.wm.edu/educationbookchapters

Part of the African American Studies Commons, Bilingual, Multilingual, and Multicultural Education Commons, Other Education Commons, and the Sports Studies Commons

\section{Recommended Citation}

Donnor, Jamel K., "Parent(s): The Biggest Influence in the Education of African- American Football Student-Athletes" (2006). School of Education Book Chapters. 17.

https://scholarworks.wm.edu/educationbookchapters/17

This Book Chapter is brought to you for free and open access by the School of Education at W\&M ScholarWorks. It has been accepted for inclusion in School of Education Book Chapters by an authorized administrator of W\&M ScholarWorks. For more information, please contact scholarworks@wm.edu. 


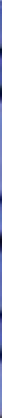

\section{CRITICAL RACE THEORY}

\section{IN EDUCATIO}

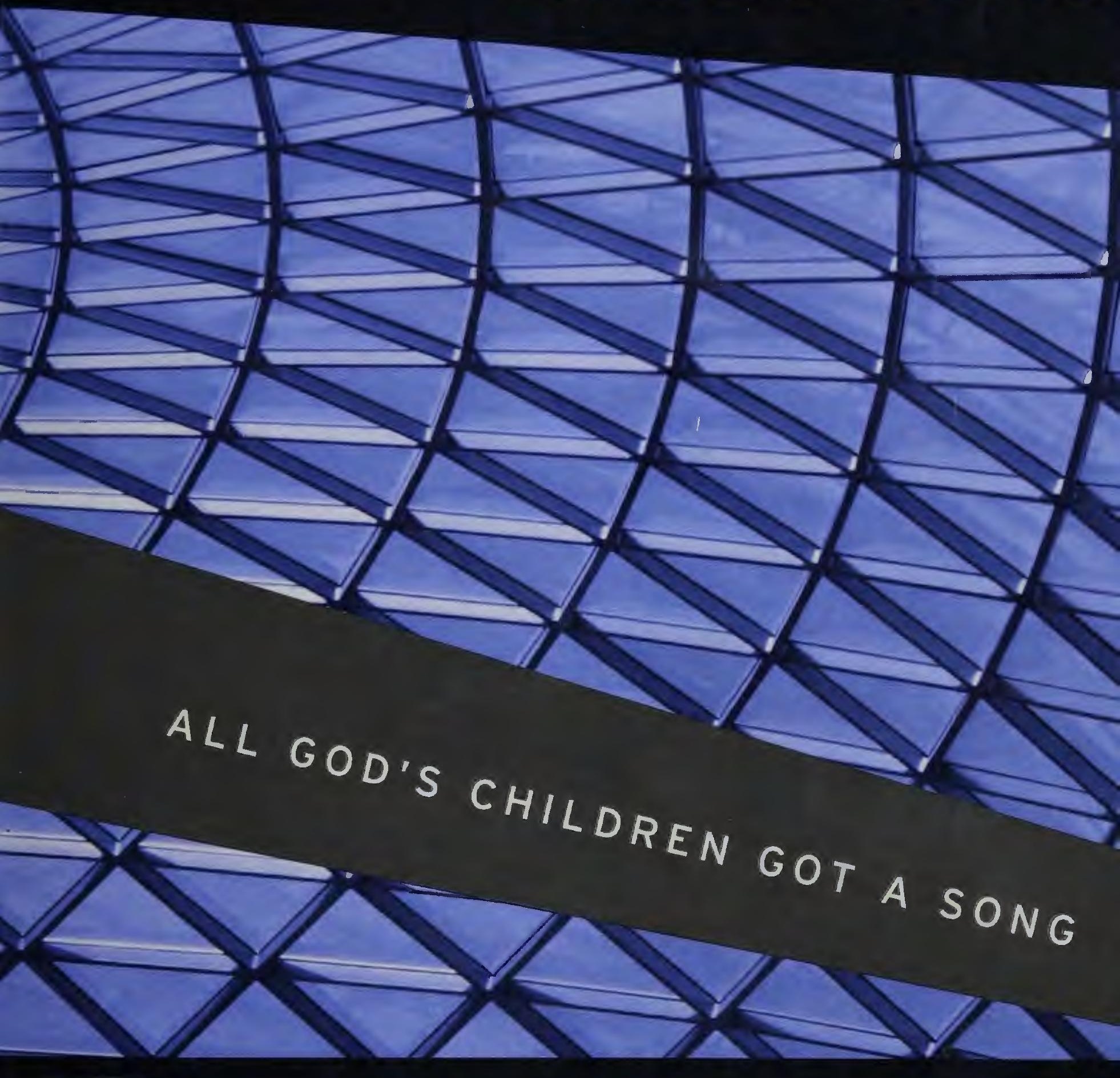

EDITED BY

ADRIENNE D. DIXSON AND CELA K. ROUSSEAU 


\section{CRITICAL RACE THEORY}

\section{IN EDUCATION}

ALL GOD'S CHILDREN GOT A SONG

EDITED BY

ADRIENNE D. DIXSON AND CELIA K. ROUSSEAU

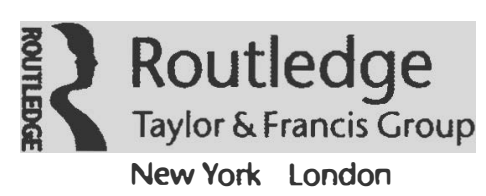

Routledge is an imprint of the

Taylor \& Francis Group, an informa business 
The Foreword and Chapters 2, 4, 9, 10 and 14 are reprinted with permission of Routledge. http://www.tandf.co.uk/journals/titles/13613324.asp

Routledge

Taylor \& Francis Group

270 Madison Avenue

New York, NY 10016
Routledge

Taylor \& Francis Group

2 Park Square

Milton Park, Abingdon

Oxon OX14 4RN

() 2006 by Taylor \& Francis Group, LLC

Routledge is an imprint of Taylor \& Francis Group, an Informa business

Printed in the United States of America on acid-free paper

10987654321

International Standard Book Number-10: 0-415-95292-1 (Softcover) 0-415-95291-3 (Hardcover)

International Standard Book Number-13: 978-0-415-95292-7 (Softcover) 978-0-415-95291-0 (Hardcover)

No part of this book may be reprinted, reproduced, transmitted, or utilized in any form by any electronic, mechanical, or other means, now known or hereafter invented, including photocopying, microfilming, and recording, or in any information storage or retrieval system, without written permission from the publishers.

Trademark Notice: Product or corporate names may be trademarks or registered trademarks, and are used only for identification and explanation without intent to infringe.

\section{Library of Congress Cataloging-in-Publication Data}

Dixson, Adrienne D.

Critical race theory in education : all God's children got a song / Adrienne D. Dixson and Celia K. Rousseau.

p. $\mathrm{cm}$.

Includes bibliographical references and index.

ISBN 0-415-95291-3 (alk. paper) -- ISBN 0-415-95292-1 (pbk. : alk. paper)

1. Critical pedagogy. 2. Racism in education. 3. Discrimination in education. I.

Rousseau, Celia K. II. Title.

LC196.D59 2006

370.11'5--dc22

2005036818

Visit the Taylor \& Francis Web site at

http://www.taylorandfrancis.com 


\section{Contents}

Foreword

V11

GLORIA LADSON-BILLINGS

Introduction

Part I: Critical Race Theory and Education in Context

1 Toward a Critical Race Theory of Education

GLORIA LADSON-BILLINGS AND WILLIAM F. TATE IV

2 And We Are Still Not Saved: Critical Race Theory in Education Ten Years Later

ADRIENNE D. DIXSON AND CELIA K. ROUSSEAU

\section{Part II: Critical Race Theory Constructs}

3 The First Day of School: A CRT Story

CELIA K. ROUSSEAU AND ADRIENNE D. DIXSON

4 Pedaling Backward: Reflections of Plessy and Brown in Rockford Public Schools' De Jure Desegregation Efforts THANDEKA K. CHAPMAN

5 "Proving Your Skin Is White, You Can Have Everything": Race, Racial Identity, and Property Rights in Whiteness in the Supreme Court Case of Josephine DeCuir JESSICA T. DECUIR-GUNBY

6 Keeping it Real: Race and Education in Memphis CELIA K. ROUSSEAU

7 Critical Race Perspectives on Desegregation: The Forgotten Voices of Black Educators JEROME E. MORRIS

8 Parent(s): The Biggest Influence in the Education of African American Football Student-Athletes 
iv - Contents

\section{Part III: The Interdisciplinary Nature of Critical Race Theory}

9 Whose Culture Has Capital? A Critical Race Theory

Discussion of Community Cultural Wealth

TARA J. YOSSO

10 Critical Race Ethnography in Education: Narrative, Inequality, and the Problem of Epistemology

GARRETT ALBERT DUNCAN

11 The Fire This Time: Jazz, Research and Critical Race Theory ADRIENNE D. DIXSON

\section{Part IV: Critical Race Theory in U.S. Classrooms and Internationally}

12 Where the Rubber Hits the Road: CRT goes to High School 233 DAVID STOVALL

13 Critical Race Theory beyond North America: Toward a Trans-Atlantic Dialogue on Racism and Antiracism in Educational Theory and Praxis

DAVID GILLBORN

14 Ethics, Engineering, and the Challenge of Racial Reform in Education

WILLIAM F. TATE IV

Index 


\section{Parent(s): The Biggest Influence in the Education of African American Football Student-Athletes}

JAMEL K. DONNOR

\section{Introduction}

African American parental involvement in education is inextricably linked with improving the political and economic standing of their children. In The Education of Blacks in the South, 1860-1935, James Anderson (1988) chronicles the efforts of ex-slaves to "establish schools for their own children" (p. 15). According to Anderson (1988), the Negroes' labors were grounded in the "belief that education could help raise freed people to an appreciation of their historic responsibility to develop a better society and that any significant reorganization of the southern political economy was indissolubly linked to their education in the principles, duties, and obligations appropriate to a democratic social order" (p. 28).

Similarly, Siddle-Walker (1996) details black parents' involvement in a high school they helped to establish for their children in North Carolina during the Jim Crow era:

Negro parents who wanted a child to have an education beyond elementary school were forced to send the child to neighboring cities in other counties, while white children could choose from among three high schools as early as 1924. ... Many Negro parents were not able to make the sacrifices such a move entailed. The parents who rose to assume the initiative in plans to start a high school in Yanceyville [North Carolina], and who continued to assume the initiative leadership roles in the school over the years, may be called 'advocates.' In general, these advocates were parents...who interposed themselves between the needs of the Negro community and the power of the white school board and made requests on behalf of the school. (p. 19) 
While the current social context shaping African American parental involvement is not as repressive as slavery or Jim Crow, the reason for participating in their child's education remains constant.

Traditionally, education scholars have categorized the relationship between the secondary education of African American males and their involvement with athletics as inherently beneficial. Highlighting sports' functional characteristics, this popular perspective suggests that student-athletes learn the value of hard work, perseverance and being goal-oriented (Eitzen, 2001 [1997]). Further, the functionalist perspective contends that involvement in athletics increases students' grades, academic aspirations and self-concept. In a study measuring Sport and Academic Resilience among African American Males, Braddock et al. (1991) suggest:

For African-American male students, this [interscholastic sports] adds an academic incentive to other intrinsic incentives already associated with sport involvement. ... Athletic participation, then, may be seen as a mechanism that both forces and facilitates academic responsiveness, thus providing both a rationale and tools for academic effort-even in the face of earlier difficulties. (p. 129)

In addition to advancing a static conception of academic success, conventional studies have ignored the contributory role of parents as stakeholders in the education of African American male student-athletes. As a result, athletics' educational value is overstated.

This chapter is a departure from the extant education research on African American males, education and sport. Moreover, it represents my interest in Derrick Bell's (1992 [1980]) "interest-convergence" theory as a framework to interpret the educational experiences of African American athletes (Donnor, 2005).* Utilizing descriptive information derived from a case study project examining the academic preparedness of African American intercollegiate football student-athletes, this chapter discusses the contributory role of parents in a student-athlete's education. Examining the educational experiences of black male student-athletes from this viewpoint, I argue, uncovers how race as an experiential construct informs parental behavior, attitudes, and decisions regarding academic achievement (Ladson-Billings, 1998, 2003; Duncan, 2005; Dixson and Rousseau, 2005).

The goals of this chapter are twofold. The first is to provide a more holistic understanding of the secondary education of African American male studentathletes. The second goal is to enrich the education literature's theorizing on race. This chapter contains five sections. The first discusses the conceptual limitations of popular theories used to examine this topic. Section two explains

* Davis (1995) used interest-convergence to explain African American integration into intercollegiate athletics. 
the interest-convergence principle and its application to a study exploring the educational experiences of African American student-athletes. The third section explains the research methods used to collect information from 17 black male student-athletes at three Midwestern universities with Division IA football programs. Section four presents ethnographic interview data describing how parents contributed to the college preparedness of African American males talented enough to play Division IA football. Section five, the conclusion, consists of a discussion and analysis of the study's findings in relation to interest-convergence theory.

\section{Traditional Theoretical Approaches}

Theoretically, scholars have used either a dialectical (e.g., conflict theory) or social psychological approach to make sense of African American studentathletes' educational experiences and outcomes. Highlighting institutional factors, conflict theorists focus on the structural and cultural dimensions of sport. Specifically, conflict theories explain the extent to which policies and standard operating procedures work to marginalize participants. For example, conflict theorists assert that at the Division IA level, football student-athletes are exploited based on the following determinants: (1) the amount of potential revenue generated by the sport, (2) coaches' salaries, (3) the total time dedicated to sport-related activities compared to academics, and (4) the fact that student-athletes are not permitted to receive a stipend (Gerdy, 2000; Patterson, 2000; Coakley, 2001). Further, conflict theorists contend that African American student-athletes are particularly vulnerable to exploitation because they are more likely to be "specially admitted"* or encouraged to enroll in "Mickey Mouse" courses to maintain athletic eligibility (Eitzen, 1999; Edwards, 1984).

Conversely, social psychologists explore issues encompassing identity formation, informal interactions, and interpersonal relationships in their examinations of student-athletes. According to the social psychological perspective, individuals identified as having athletic talent are "foreclosed" from developing characteristics associated with being a good student to pursue success in sports (Watt and Moore, 2001, p. 340). According to Webb et al. (1998), the "time and psychological commitment to the [social] role of athlete is such that by the time they reach high school, highly successful athletes have internalized the athletic identity, frequently at the expense of other social roles" ( $\mathrm{p}$. 340). Consequently, overidentification with the social role of athlete can result in the unintentional perpetuation of the pervasive image of the intellectually deficient athlete (the "dumb jock") (Gerdy, 2002, p. 69; Edwards, 1984).

* This term refers to a student, irrespective of athletic status, who has not met a university's conventional requirement for admission. Legacy admissions and early enrollees are examples of special admits. 
Social psychologists also contend that student-athletes disproportionately experience conflict between the demands of sport and education. In addition to addressing nonathletic responsibilities, such as developing "personal competencies that will enable them to bring about a greater degree of mastery and control over their environment," student-athletes must "balance" athletic requirements, adapt to a "certain degree of isolation from mainstream activities," and "satisfy multiple relationships" with coaches, parents, friends and the community (Parham, 1993, p. 412). Unlike conflict theorists, social psychologists recognize the interplay among racial, gendered and athletic identities in the education of African American student-athletes. For instance, because the majority of black college football players come from lower socio-economic backgrounds, social psychologists assert that their chances for academic success are less than those of whites (Harris, 2000).*

Though adequate, both strands of thought conceptually restrict education, individual experience, agency and race to the athletic environment. For instance, conflict theorists minimize in-group variance by not accounting for the academic achievement of student-athletes despite the pressure for athletic success. Similarly, the social psychological framework exaggerates the obvious among African American student-athletes. The majority of African American student-athletes who participate in Division IA football come from urban schools. As a result, the social psychological perspective generalizes that all black males' chances for success are poorer because of their background. Stated differently, social psychology does not explore or consider the differences within this group, and how they may be successful because of their background. Benson's (2000) work on the academic achievement of African American Division I football players suggests that a reconceptualization is necessary to understand this phenomenon. According to Benson, "marginal academic performance [is] a phenomenon created by a series of interrelated practices engaged by all significant members of the academic setting, including peers, coaches, advisors, teachers/professors, and the student-athletes themselves" (p. 229). I believe that Derrick Bell's (1992 [1980]) interest-convergence principle (ICP) provides the conceptual space necessary to develop a more nuanced explication of the black athlete's educational experience than the aforementioned theories can.

\section{The Interest-Convergence Theory}

Interest-convergence is an analytical construct of critical race theory (CRT) that explains the political economics of race in America (Bell, 1992 [1980], 1987; Delgado and Stefancic, 2005; Tate, 2005). Premised on a racial group's "legal history," interest-convergence describes the tensions between legal

* The 2005 graduation rates as reported by the National Collegiate Athletic Association (NCAA) supports this. 
redress for racism and maintenance of the political and economic status quo. Legal history establishes a social context for understanding the "world as it is rather than how we might want it" (Bell, 1995, p. 22). Bell developed the interest-convergence thesis to explain external societal factors that influenced the U.S. Supreme Court's decision in Brown v. Board of Education. According to Bell (1992 [1980]),

Until Brown, black claims that segregated public schools were inferior had been met by orders requiring merely that facilities be made equal. Courts had been willing to substitute their judgments for those of the legislatures as to the wisdom of school segregation policies. The decision in Brown to break with its long-held position on these issues, despite the language of the opinion, can't be understood without some consideration of the decision's impact on interests other than those of long-suffering black children and their parents. (p. 640).

Bell (1992 [1980], 2004) hypothesized that as America began to position itself as a "world" leader by advocating that Third World countries adopt democracy and capitalism as political and economic alternatives to communism after World War II, images broadcast internationally of black Americans' sanctioned oppression (i.e., segregation) and physical repression during the civil rights movement hindered America's democracy project. Segregation no longer contributed to the advancement of U.S. domestic and foreign policies.

Conducting a document analysis of formerly confidential Supreme Court memoranda and classified government documents, Dudziak (1988) found:

Newspapers throughout the world carried stories about discrimination against non-white visiting foreign dignitaries, as well as against American blacks. At a time when the U.S. hoped to reshape the postwar world in its own image, the international attention given to racial segregation was troublesome and embarrassing. The focus of American foreign policy at this point was to promote democracy and to 'contain' communism. However, the international focus on U.S. racial problems meant that the image of American democracy was tarnished. The apparent contradictions between American political ideology and practice led to particular foreign policy difficulties with countries in Asia, Africa and Latin America. U.S. government official realized that their ability to sell democracy to the Third World was seriously hampered by continuing racial injustice at home. (p. 62)

In this instance of social "progress," the Supreme Court was more interested in providing "immediate credibility to America's struggle with communist countries to win the hearts and minds of emerging third world people," instead of doing what was morally right (Bell, 1995, p. 23). Further, public schools were selected because they "represented a far more compelling symbol of the evils 
of segregation and a far more vulnerable target than segregated railroad cars, restaurants, or restrooms" (Bell, 1995, p. 229).

Interest-convergence puts into full view the limitations and contradictions of law and public policy by pointing out how they operate to secure the dominant class's interests. Paradoxically, the rights of oppressed groups are recognized and legitimated only when they further the interests of the dominant class and of society's governing institutions. Moreover, the identification of the motivating factors that guide policy development, as in Brown, suggests that the coincidence of a pressing political and/or economic issue is required rather than a commitment to social justice.

For this study, interest-convergence theory provides the conceptual space to explore the educational history of African American student-athletes, including the behavior and motivation of educational stakeholders (e.g., parents, teachers and peers) in the process. Moreover, interest-convergence theory recognizes parents' interests in academic and athletic achievement as external factors that influence student-athletes' academic choices by developing education's and sport's (intrinsic) value. For example, if parents construct sport as the primary mechanism for improving social and economic standing, a student-athlete might be susceptible to selecting nonrigorous classes. Conversely, if academic achievement is promoted and sport is simultaneously deemphasized by parents, a black male athlete may be more likely to enroll in classes that will prepare him for college. Unlike Bell's (1992 [1980]) use of interest-convergence to uncover the ways in which inequity gets recycled under the guise of "equal opportunity" to advantage the privileged, I used ICP to explore factors outside education that contribute to the academic advancement of African American student-athletes.

\section{Methodology}

The use of interest-convergence theory required research methods that allow for consideration of: (1) history and current socio-cultural context, (2) experiential knowledge, and (3) the comparison of similar experiences. Case study and ethnographic interviews were selected as data collection methods because of their potential to extract information that is descriptive, interpretive and comparative (Stake, 1995; Merriam, 1998; Yin, 2003; Cohen, Manion and Morrison, 2000). By suggesting that the academic advancement of African American student-athletes is a convergence of interests, I am attempting to examine and define a set of explicit and implicit actions, attitudes and interactions within a specific setting. Moreover, the case study method was chosen because of its ability to "retain the holistic and meaningful characteristics of real-life" (Yin, 2003, p. 2). In addition, case study supports the investigation and reporting of "complex dynamic and unfolding interactions" between student-athletes and parents (Cohen, Manion and Morrison, 2000). 
I also used ethnographic interviewing techniques to collect data and make sense of such "operational links," rather than simply measuring for randomness (Merriam, 1998). I grouped the interview questions posed to the black athletes in this study into the following categories: (1) descriptive, (2) structural, (3) contrasting, and (4) interpretive (Spradley, 1979; Merriam, 1998). I designed the descriptive questions to elicit a "large sample of utterances in the informant's native language" (Spradley, 1979, p. 85). An example of a descriptive question I posed was How would you describe your educational experience before being identified as possessing the athletic ability to play for a major college program in high school? I adapted structural questions specifically to the particular participant (Spradley, 1979). For example, I asked a structural question like Who is responsible for ensuring a student-athlete is prepared in high school? I used contrasting questions to discover variations among participants. An example of a contrasting question is Do you think there are differences in the way black student-athletes and non-student-athletes are educated? Finally, interpretive questions allowed for "reliability" because they check for understanding of the informant's responses (Merriam, 1998). An example is How important would you say parents are in the education of African American student-athletes?

\section{Sampling}

Participants were both purposely and randomly selected. I intentionally sought first-year student-athletes for their ability to provide a rich delineation of whether they were academically prepared for college. I selected sophomore respondents based on their advanced involvement in athletics and education. According to NCAA (2005) policy, a student-athlete must declare an academic major by his or her junior year in college. Thus, sophomores are best situated to reflect on how or if their values as educational stakeholders have shifted because of their continued association with athletics and its effects on education-related choices. Access to the remaining participants was provided through a collegial relationship I had with a professor at an institution. Because of this, I interviewed senior African American student-athletes. This group supplied a comprehensive assessment of their academic preparation by sharing their insights on the impact of the actions and decisions of significant others on their educational careers.

\section{Findings}

A major finding of this study is the centrality of parents to the education of African American male student-athletes. According to Chris (this and other names are pseudonyms), a freshman, "They [parents] are huge ... that is where education starts." Likewise, Anthony, a sophomore, stated, "A lot of it [education] falls on the parents whether or not a student-athlete is successful in high school." More specifically, parental interests in the student-athlete's academic advancement were grounded in the larger concept of "wanting me [student-athlete] to 
have a better life than them." In other words, according to the student-athletes who participated in this study, parents viewed education, and high academic achievement in particular, as essential for improving a student-athlete's overall quality of life.

The participants told about specific activities parents engaged in to ensure their preparation for college. Parental involvement varied from enrolling the participant in private school, to having discussions on race and academic achievement, to deemphasizing sport. The following vignettes provide insight into how the attitudes and actions of specific family members served the black athlete's educational interests.

James, a freshman, spoke of how his parents paid for him to attend private school, with their individual educational experiences serving as a personal template:

My parents struggled to pay for private school. That showed me where they placed education on their hierarchy. Also, my father was born in Guyana and his family came here [United States] from Guyana when he was ten. They [father's parents] were high on education so he instilled it in me and my sisters. Also, my mother went to UT-Austin and was a 4.0 student. She graduated in three years with a 4.0. All of my life, my parents put a really high emphasis on education.

Leon, a senior, also discussed how his parents sent him to a private high school and how it positioned him for college:

My parents decided to send me to a private school because I was not making any progress in public school. There is only one public high school in my town. It is also home to the middle school, which means it actually starts from seventh grade whereas a traditional high school begins in the ninth grade. My mother and my father made the decision to send me to another school because they figured that would be the best thing for me. I did not like it at first, but it ended up being the best thing that happened to me. It was not until my senior year, that I realized that if I stayed at my original school, I would not be in the position to be deciding where to go to college.

Robeson, a freshman, discussed his father's political view of the endemic nature of racism in America and the need for black males to be the best:

My dad is the one who pushed me to get 4.0 every quarter in high school. My dad told me that it is racial, if it's between you and a white person, you always are going to lose because that is society's mindset. They [whites] don't want to give you a chance over them. So that is the mindset I have right now. Anything I do, it can't be close. 
Ray, a freshman, talked about his mother as a role model, and her attitude on doing well in high school:

She led by example because in high school she played sports and was top in her class. She lived in a predominantly white town so she had to deal with a lot more prejudice. ... As my athletic ability started to take off, I did not slack off but my grades certainly were not the same. My mom kept telling me you have to get a 4.0, if you do not, you will be attending college right around the corner at a community college because I'm not going to pay a lot of money for you to go somewhere where you would not put forth the effort you could have right now. So my last two years of high school, I got right around a 3.2. I started taking AP classes so my studies would become more difficult.

Steven, a sophomore, acknowledged his father's laser-like focus on education:

He was always there at the games, and he was always on me about school work. That is the reason why I am where I am now. He would not let me slack off on my grades no matter what was going on. Even though he loves football and knew how important it was to me, he only talked about my grades. Even when my grades were not bad, he would always say you can do better. He was the biggest influence.

As illustrated by these vignettes, parental interests place African American football student-athletes in a better position to have a rewarding education. This study's use of the interest-convergence principle illustrates how African American parents negotiated race, education, and sport. Further, the manner in which race informs the configuring of black parents' attitudes and actions in their child's education is historically consistent (see the introduction). Specifically, ICP illuminates the complexities involving parents, student-athletes, sport, and education by showing how they converge to contribute to the black student-athlete's achievement. For example, Robeson's father's discussion of the life-long significance of education versus athletics supports this assertion:

The most important thing in your life, always and forever ... football is good, but if you blow out your knee and cannot walk again then you are done. ... You always got your brain to fall back on. Academics come first, because it is going to be with you for the rest of your life.

\section{Discussion}

This chapter contributes to the field of education research in two ways. The first contribution is theoretical. Interest-convergence counters the positivistic perspectives that dominate the field. Unlike traditional studies that suggest an intrinsic connection among African American males, educational success and athletics, the ethnographic interviews from this study suggest parents are 
the primary factor in the scholastic achievement of African American student-athletes. This is noteworthy because it interrogates the functional viewpoint that involvement in athletics naturally enhances student's academic performance. Sport, for the majority of participants at the secondary level, is inconsequential to academic success. More important, accounts of parental involvement highlight how sport diverges from their educational values.

A second theoretical contribution of this study is the rejection of deficit viewpoints. Benson (2000) asserts that there are significant data that attribute underachievement of intercollegiate African American male football student-athletes to poor high school preparation: "Problems within society at large suggesting that these students' underachievement may be caused in part by the way that schools are structured to maintain the prevailing social and economic order" (p. 223). Rather, this study recognizes the multiple contexts in which African American males, education and sport are positioned. For instance, Steven's father acted to convey a sense of balance between education and athletics, suggesting that student-athletes possess a modicum of control over athletic experience by regulating the demands of academics. Moreover, balance rebuts the social psychological assertion that athletic "over-conformity" conflicts with being a successful student (Webb et al., 1998). Hence, balance provides a tangential benefit to the student-athlete.

The second contribution this chapter makes to the education field is methodological. Case and ethnographic interviews are research methods that provide a clearer understanding of the education of black football student-athletes. A case study supports general understanding, whereas the information obtained from ethnographic interviews provided the "rich" data (details) for this project. The participants' narratives bridge the high school and collegiate settings, which gave me with a more complete understanding of their educational experience. The interviewees' shared and individual "stories" showed how race and competing self-interests contributed to academic performance through a series of interrelated practices involving parents as educational stakeholders. Finally, having the respondents of this study "name their reality" is contributory because it rejects outright the deficit and social reproductive perspectives that dominate this topic.

\section{References}

Anderson, J.D. (1988). The Education of Blacks in the South, 1860-1935. Chapel Hill: University of North Carolina Press.

Bell, D. (1987). And We Are Not Saved: The Elusive Quest for Racial Justice. New York: Basic Books. Bell, D. (1992 [1980]). Race, Racism and American Law. 3rd ed. Boston: Little, Brown.

Bell, D. (1995). Brown v. Board of Education and the Interest Convergence Dilemma. In K. W. Crenshaw et al. (eds.), Critical Race Theory: The Key Writings That Formed the Movement, 20-29. New York: New Press.

Bell, D. (2004). Silent Covenants: Brown v. Board of Education and the Unfulfilled Hopes for Racial Reform. New York: Oxford University Press.

Benson, K. F. (2000). Constructing Academic Inadequacy: African American Athletes' Stories. Journal of Higher Education 71(2): 223-246. 
Braddock, J. H. II; Royster, D. A.; Winfield, L. A.; and Hawkins, R. (1991). Bouncing Back: Sport and Academic Resilience among African-American Males. Education and Urban Society 24(1): 113-131.

Coakley, J. J. (2001). Sport in Society: An Inspiration or an Opiate? In D. S. Eitzen (ed.), Sport in Contemporary Society, 20-37. New York: Worth.

Cohen, L.; Manion, L.; and Morrison, K. (2000). Research Methods in Education. 5th ed.. London: RoutledgeFalmer.

Delgado, R., and Stefancic, J. (2005). Introduction. In R. Delgado and J. Stefancic (eds.), The Derrick Bell Reader, 1-15. New York: New York University Press.

Dixson, A. D., and Rousseau, C. K. (2005). And We Are Still Not Saved: Critical Race Theory in Education Ten Years Later. Race, Ethnicity and Education 8(1): 7-27.

Donnor, J. K. (2005). Towards an Interest-Convergence in the Education of African American Football Student Athletes in Major College Sports. Race, Ethnicity and Education 8(1): 45-67.

Dudziak, M. L. (1988). Desegregation as a Cold War Imperative. Stanford Law Review 41(61): $1-61$.

Duncan, G. (2005). Critical Race Ethnography in Education: Narrative, Inequality, and the Problem of Epistemology. Race, Ethnicity and Education 8(1): 95-116.

Edwards, H. (1984). The Black "Dumb Jock": An American Sports Tragedy. College Board Review no. 131: 8-13.

Eitzen, D. S. (1999). Fair and Foul: Beyond the Myths and Paradoxes of Sport. Lanham, MD: Rowman and Littlefield.

Eitzen, D. S. (2001 [1997]). Big-time College Sports: Contradictions, Crises, and Consequences. In D. S. Eitzen (ed.), Sport in Contemporary Society: An Anthology, 201-212. 6th ed. New York: Worth.

Gerdy, J. R. (2000). College Athletics as Good Business? In J. R. Gerdy (ed.), Sports in School: The Future of an Institution, 42-54. New York: Teachers College Press.

Gerdy, J. R. (2002). Sports: The All-American Addiction. Jackson: University of Mississippi Press. Harris, O. (2000). African American Predominance in Sport. In D. Brooks and R. Althouse (eds.), Racism in College Athletics: The African American Athlete's experience, 37-52. Morgantown, WV: Fitness Information Technology.

Hartmann, D. (2000). Rethinking the Relationships between Sport and Race in American Culture: Golden Ghettos and Contested Terrain. Sociology of Sport Journal 17: 229-253.

Ladson-Billings, G. (1998). Just What Is Critical Race Theory and What's It Doing in a Nice Field like Education? Qualitative Studies in Education 11(1): 7-24.

Ladson-Billings, G. (2003). It's Your World, I'm Just Trying To Explain It: Understanding Our Epistemological and Methodological Challenges. Qualitative Inquiry 9: 5-12.

Merriam, S. B. (1998). Qualitative Research and Applications in Education. San Francisco: Jossey-Bass.

Parham, W. D. (1993). The Intercollegiate Athlete: A 1990s Profile. Counseling Psychologist 21(3): 411-429.

Patterson, C. M. (2000). Athletics and the Higher Education Marketplace. In J. R. Gerdy (ed.), Sports in School: The Future of an Institution, 119-127. New York: Teachers College Press.

Siddle-Walker, V. (1996). Their Highest Potential: An African American School Community in the Segregated South. Chapel Hill: University of North Carolina Press.

Spivey, D., and Jones, T. A. (1975). Intercollegiate Athletic Servitude: A Case Study of the Black Illini Student-Athletes, 1931-1967. Social Science Quarterly 55: 939-947.

Spradley, J. P. (1979). The Ethnographic Interview. New York: Holt, Rinehart and Winston.

Stake, R. E. (1995) The Art of Case Study Research. Thousand Oaks, CA: Sage.

Tate, W. F. (1999). Conclusion. In L. Parker et al. (eds.), Race Is ... Race Isn't: Critical Race Theory and Qualitative Studies in Education, 251-271. Boulder, CO: Westview.

Tate, W. F. (2005). Brown, Political Economy, and the Scientific Education of African Americans. Review of Research in Education 28: 147-184.

Taylor, E. (1999). Bring in "Da Noise": Race, Sports, and the Role of Schools. Educational Leadership 56(7) 75-78.

Watt, S. K., and Moore, J. L., III (2001). Who Are Student Athletes? New Directions for Student Services 93: 7-18.

Webb, W.; Nasco, S. A.; Riley, S.; and Headrick, B. (1998). Athletic Identity and Reactions to Retirement from Sports. Journal of Sport Behavior 21(3): 338-358.

Yin, R. K. (2003). Case Study Research: Design and Methods. 3rd ed. Thousand Oaks, CA: Sage. 